\title{
N87-29933
}

\section{APPLICATION OF ADVANCED FLYWHEEL TECHNOLOGY FOR ENERGY STORAGE ON SPACE STATION*}

\author{
M. Olszewski \\ Oak Ridge National Laboratory \\ Oak Ridge, Tennessee 37831
}

In space power applications where solar inputs are the primary. thermal source for the power system, energy storage is necessary to provide a continuous power supply during the eclipse portion of the orbit. Because of their potentially high storage density, flywheels have been given consideration for use as the storage system on the proposed orbiting space station.

During the past several years graphite fiber technology has advanced, and this has led to significant gains in flywheel storage density. The tensile strength of current fibers is a factor of two to three higher than previous materials. Use of these improved fibers in experimental flywheel rims has resulted in ultimate storage densities of $878 \mathrm{~kJ} / \mathrm{kg}$ being achieved.

With these high-strength graphite fibers, operational storage densities for flywheel storage modules applicable to the space station storage need could reach $200 \mathrm{~kJ} / \mathrm{kg}$. This module would also be volumetrically efficient occupying only about $1 \mathrm{~m}^{3}$. Because the size and mass of the flywheel storage module are controlled by the storage density, improvements in fiber strength can have a significant impact on these values. With improvements in fiber strength that are anticipated within the next five years, operational storage densities on the order of $325 \mathrm{~kJ} / \mathrm{kg}$ may be possible for the flywheel module.

\section{INTRODUCTION}

Space power systems using a solar primary energy source, require an energy storage component to maintain operation of the platform during the eclipse portion of the orbit. Flywheels offer a number of advantages that make them attractive for such systems. They possess relatively high energy storage densities; this results in a low storage system mass. Also, the power density of the flywheel is independent of the energy density and is fixed by the output device rather than the flywheel. This results in a storage system whose charging and discharging rates can differ greatly without affecting its performance. In addition, the rotating mass of the flywheel can provide for attitude control of the space platform, while also fulfilling its energy storage role. Because of these valuable operating characteristics, NASA has sponsored several flywheel workshops (refs. 1 and 2) and has investigated a concept

\footnotetext{
* Research sponsored by the Office of Nuclear Energy under U.S. DOE contract No. DE-ACO5-840R21400 with Martin Marietta Energy Systems, Inc.,

The submitted manuscript has been authored by a contractor of the U.S. Government under contract No. DE-AC05-840R21400. Accordingly, the U.S. Government retains a nonexclusive, royalty-tree license to publish or reproduce the published form of this contribution, or allow others to do so for U.S. Government purposes.
} 
that integrates energy storage and attitude control functions (ref. 3 ) in a single flywheel module.

In this paper, advances in flywheel performance are detailed and potential improvements estimated. A flywheel energy storage module suitable for the needs of the space station is described. Performance of the module, in terms of energy storage density, is estimated using demonstrated flywheel performance. In addition, anticipated improvements in flywheel storage densities are used to determine potential performance increases for the storage module.

\section{FLYWHEEL LEVELOPMENT}

\section{Flywhee1 Rotor Materials}

In space power applications, minimization of system mass is a critical design parameter. For the flywheel designer, this translates into a requirement that the storage system possess the highest possible storage density. As shown in Table 1 , this necessitates that the flywheel rotor be constructed of composite material.

\section{Early Composite Flywheel Performance}

Composite flywheel technology was initially established in the Mechanical Energy Storage Technology (MEST) Program conducted by the Oak Ridge National Laboratory (ref. 4). In the initial stages of the program, a number of rotor designs (configurations and materials) were fabricated and tested. The purpose of these initial tests was to determine the performance limits of the design and verify rotor failure mechanisms. Thus, the testing regime was limited to ultimate speed evaluations. The performance results of these initial ultimate speed tests are given in Table 2. The energy density and stored energy figures represent the rotor's capability at the maximum speed attained in the test. Actual operational values would, of course, be lower. The highest ultimate energy density achieved was $266 \mathrm{~kJ} / \mathrm{kg}$ with a subcircular Kevlar rim design. Following closely, at $233 \mathrm{~kJ} / \mathrm{kg}$, was a disk/ring design made of graphite and S-glass. The highest stored energy, $7.67 \mathrm{MJ}$, was achieved with a graphite overwrap configuration.

For the second stage of testing in the MEST Program, the field of candidate rotors was narrowed; and the testing regime expanded to include cyclic fatigue tests. Results of these tests are given in Table 3. The disk and disk/rim rotors completed the full 10,000 cycle test. Subsequent ultimate speed tests of these rotors yielded energy densities of 175 and $229 \mathrm{~kJ} / \mathrm{kg}$, respectively. The disk/rim results were particularly instructive, because ultimate speed data were obtained for rotors with no cycles and with 10,000 cycles. Comparison of the energy density achieved in the two tests $(233 \mathrm{~kJ} / \mathrm{kg}$ and $229 \mathrm{~kJ} / \mathrm{kg})$ indicated that there was no degradation in pertormance through 10,000 cycles.

\section{Advances in Flywheel Performance}

The MES'T Program was phased out in 1983, and flywheel technology was essentially frozen at these performance levels. Flywheel development activities resumed at 0ak Ridge in 1985, and significant advances in rotor performance were achieved through precision fabrication of carbon fiber/epoxy material (ref. 5). The fibers used were Hercules IM6 and AS6. The Hercules IM6 fiber came to the market in 1985 and represented a significant improvement in fiber strength. Previous graphite fibers had 
ultimate tensile strengths on the order of $2640 \mathrm{MPa}(383 \mathrm{ksi})$. The IM6 fiber at $5340 \mathrm{MPa}$ (775 ksi) more than doubled this strength and led to significant advances in flywheel performance.

The focus of this effort was the design, fabrication, and spin testing of carbon/epoxy flywheels using the advanced high-strength fibers. The first series of rims to be tested (the only ones to be tested to date) was designated the Demo 1 series. To construct the rotors, fibers were wet wound and cured on a mandrel to form a thick-walled cylinder. The fabricated cylinder was then sectioned to form the test rims. In this design, the lower-modulus higher-strength material (IM6) was used for the outer portion of the rim and AS6 for the inner portion.

Test results for the Demo 1 series are summarized in Table 4 and compared with the MEST results in Figure 1 . Since the purpose of the program was to demonstrate advances in rotor technology, no attempt was made to optimize the web structure. In these tests, the web structures were relatively heavy being about equal to the rim weight. In an optimized system, the web would be much lighter (potentially on the order of $20 \%$ of the rim weight). Consequently, the data points for "rim + web" do not reflect a typical design.

The most dramatic result was obtained with Demo lC. This rotor was intentionally accelerated until failure occurred at a peripheral speed of $1405 \mathrm{~m} / \mathrm{s}$. At this speed, the energy density of the rim only was $878 \mathrm{~kJ} / \mathrm{kg}$. The total kinetic energy stored by the unit (rim + web) was $7.28 \mathrm{MJ}$. The $1405 \mathrm{~m} / \mathrm{s}$ peripheral velocity was an increase of $\sim 40 \%$ over previous spin tests. The demonstrated failure speed of $1405 \mathrm{~m} / \mathrm{s}$ provides firm experimental evidence for a safe flywheel design operating speed in the range of 1100 to $1200 \mathrm{~m} / \mathrm{s}$.

SPACE STATIUN FLYWHEEL STURAGE MOUULE

\section{Module Configuration}

A schematic for a flywheel energy storage concept applicable to the needs of the space station is shown in Figure 2. This concentric configuration was chosen because it is highly efficient in its volumetric characteristics. The flywheel module would consist of two such flywheels. Energy is stored in the two counter-rotating flywheel rotors, which are aligned on a common axis. This results in the momentum vectors of the two flywheels canceling and the platform experiencing a zero net momentum vector. A highly efficient (on the order of 96\%), lightweight (specific power of $5 \mathrm{~kW} / \mathrm{kg}$ ) axial gap permanent magnet motor/generator is used for charging and discharging the flywheel. The suspension system uses magnetic bearings to achieve very low drag and minimize standby losses. This also allows the bearing stiffness to be adjusted during operation of the system.

\section{Estimated System Performance}

Mass estimates were prepared for the flywheel storage module illustrated in Figure 2. In performing the analysis, it was assumed that the required module output power was $87.5 \mathrm{~kW}$. The time available for charging (solar time during orbit) was set at 55 minutes, and the discharge time (eclipse portion of the orbit) was assumed to be 36 minutes.

The flywheel operational storage density was governed by several major assump- 
tions. The maximum operating speed of the flywheel was limited to $80 \%$ of the burst speed. A $2: 1$ speed ratio was used resulting in a 75\% depth of discharge (on an energy basis). For efficiency in material use, a relatively thin rim was used; the ratio of inner to outer radius was set at 0.85 .

The flywheel rotor was examined at three technology levels. With currently available fibers, a burst speed of $1405 \mathrm{~m} / \mathrm{s}$ has been demonstrated. This yields a maximum operating speed of $1125 \mathrm{~m} / \mathrm{s}$ and an operational storage density of $410 \mathrm{~kJ} / \mathrm{kg}$ for the rim only. Within the next several years, it is anticipated that fiber strength can increase by about $13 \%$. This would raise the maximum operational speed to $1190 \mathrm{~m} / \mathrm{s}$ and produce an operational storage density of $460 \mathrm{~kJ} / \mathrm{kg}$ ( $\mathrm{rim}$ only). within the next five years, fibers may be available that would permit operational maximun speeds to reach $1400 \mathrm{~m} / \mathrm{s}$. With these fibers the flywheel operational storage density would be $650 \mathrm{~kJ} / \mathrm{kg}$ (again, rim only).

Previous analysis of flywheel storage modules designed for low power (on the order of $100 \mathrm{~kW}$ ) applications with charge/discharge time ratios near unity have indicated that the module operational storage density is about half that of the rim only value (ref. 5). Using this relationship results in the flywheel module operational storage densities shown in Table 5. As indicated, the module operational storage density, using current fibers, would be $205 \mathrm{~kJ} / \mathrm{kg}$. A modest $10 \%$ improvement is anticipated within the next several years resulting in a module storage density of $230 \mathrm{~kJ} / \mathrm{kg}$. With fiber technology advances anticipated within the next five years, the module storage density could be raised to $325 \mathrm{~kJ} / \mathrm{kg}$.

Since the concentric design has all power components within the bore of the flywheel, the module volume is fixed by the size and shape of the flywheel rotor. In sizing the rotor, it was assumed that the rotor length was equal to the rotor diameter. This criterion was used to determine the volume occupied by the modules designed to meet the storage needs of the space station. As indicated in Table 5, the storage module, using current fibers, would occupy $1.07 \mathrm{~m}^{3}$. Within two years, advances in fiber technology would result in the volume being reduced to under $1 \mathrm{~m}^{3}$. With the longer term advances, the module volume could potentially be reduced to $0.67 \mathrm{~m}^{3}$.

Another measure of the volumetric storage efficiency is given by the volumetric storage density. As shown in Table 5 with present technology levels, the module stores $177 \mathrm{MJ}$ in one cubic meter. This could rise to $199 \mathrm{MJ} / \mathrm{m}^{3}$ within two years and $282 \mathrm{MJ} / \mathrm{m}^{3}$ within 5 years, if the anticipated increases in fiber strength are realized.

\section{CONCLUDING KEMARKS}

The flywheel module appears to be an attractive energy storage option for the space station application. With current fibers, the system operational energy storage density is expected to be $205 \mathrm{~kJ} / \mathrm{kg}$. This compares favorably with battery and fuel cell systems, which are anticipated to be in the range of 25 to $75 \mathrm{~kJ} / \mathrm{kg}$ (refs. 1 and 2). In addition, the flywheel module is volumetrically more efficient than the competing systems. The flywheel volumetric storage density of $177 \mathrm{MJ} / \mathrm{m}^{3}$ is about an order of magnitude higher than that of battery systems (from ref. 1 the volumetric density of $\mathrm{NiCd}$ batteries is about $25 \mathrm{MJ} / \mathrm{m}^{3}$ ).

If anticipated increases in fiber strength are realized, the performance of the 
flywheel storage module would increase substantially. If fiber strength increases are fully realized, it will be possible to raise the storage density (on a mass basis) to $325 \mathrm{~kJ} / \mathrm{kg}$ with a volumetric density of $282 \mathrm{MJ} / \mathrm{m}^{3}$.

\section{REFERENCES}

1. Keckler, C.R., et al., "Integrated Flywheel Technology 1983," Proceedings of workshop held at Greenbeıt, MD, August 2-3, 1983, NASA Conference Publication 2290 .

2. Keckler C. R., et a1., "An Assessment of Integrated F1ywheel System Technology," Proceedings of Conference held at Huntsville, AL, February 7-9, 1984, NASA Conference Publication 2346.

3. Van Tassel, K. E. and Simon, W. E., "Inertial Energy Storage for Advanced Space Station Applications," Proceedings of 20th Intersociety Energy Conversion Engineering Conference, Miami Beach, FL, August 18-23, 1985.

4. Olszewski, M., "Flywheel Performance: Current State-of-the-Art," Proceedings of 19 th Intersociety Energy Conversion Engineering Conference, San Francisco, CA, August 19-24, 1984.

5. Olszewski, M. and O'Kain, D. U., "Advances in Flywheel Technology for Space Applications," Proceedings of 2lst Intersociety Energy Conversion Engineering Conference, San Diego, CA, August 25-29, 1986. 
Table 1. Characteristics of materials used in flywheels

\begin{tabular}{lccc}
\hline Material & $\begin{array}{c}\text { Ultimate tensile } \\
\text { strength }(\sigma) \\
\mathrm{MPa}\end{array}$ & $\begin{array}{c}\text { Density } \\
\mathrm{g} / \mathrm{cm}^{3}\end{array}$ & $\begin{array}{c}\sigma / \rho \\
{[\mathrm{kJ} / \mathrm{kg}(\mathrm{Wh} / \mathrm{kg})]}\end{array}$ \\
\hline Steels & 1517 & 7.7 & $197(54.7)$ \\
4340 & 2070 & 8.0 & $259(71.8)$ \\
$18 \mathrm{Ni}(300)$ & & & $726(201.6)$ \\
Composites & 1379 & 1.9 & $1089(302.5)$ \\
E-glass/epoxy & 2069 & 1.9 & $1379(382.9)$ \\
S-glass/epoxy & 1930 & 1.4 & $1057(293.7)$ \\
Kevlara epoxy & 1586 & & 328 (91.1) \\
Graphite epoxy & & 8.0 & \\
Other & 2627 & & \\
METGLASs & &
\end{tabular}

Table 2. Performance results for initial ultimate speed configuration tests

\begin{tabular}{|c|c|c|c|c|}
\hline Manufacturer & Wheel type & Material ${ }^{a}$ & $\begin{array}{c}\text { Energy density at } \\
\text { maximum speed } \\
(\mathrm{KJ} / \mathrm{kg})\end{array}$ & $\begin{array}{l}\text { Energy } \\
\text { stored } \\
(\mathrm{MJ})\end{array}$ \\
\hline ORNL & Overwrap & K49 & 178 & 2.02 \\
\hline Brobeck & Rim & $\mathrm{SG} / \mathrm{K} 49$ & 229 & 2.55 \\
\hline $\begin{array}{l}\text { Garrett/ } \\
\quad \text { AiResearch }\end{array}$ & Rim & K49/K29/SG & 266 & 4.43 \\
\hline Rocketdyne & Overwarp Rim & G & 143 & 7.67 \\
\hline APL-Metglass & Rim & $M$ & 81 & 0.14 \\
\hline Hercules & $\begin{array}{l}\text { Disk (Contoured } \\
\text { Pierced) }\end{array}$ & G & 135 & 3.06 \\
\hline AVCO & Disk (Pierced) & SG & 158 & 1.44 \\
\hline LLNL & Disk (Tapered) & $\mathrm{C}$ & 225 & 1.12 \\
\hline LLNL & Disk (F1at) & SG & 242 & 0.58 \\
\hline GE & $\begin{array}{l}\text { Disk (Solid/ } \\
\text { Ring) }\end{array}$ & $\mathrm{SG} / \mathrm{G}$ & 233 & 2.37 \\
\hline \multirow[t]{4}{*}{ Owens / Lord } & Disk & SMC & 63 & 0.61 \\
\hline & Disk/Ring & $\mathrm{SMC} / \mathrm{G}$ & 90 & 1.01 \\
\hline & & $S M C / G$ & 100 & 1.30 \\
\hline & & $\mathrm{SMC} / \mathrm{G}$ & 132 & 1.44 \\
\hline 11 & $\begin{array}{l}G=G r a p \\
\text { molding }\end{array}$ & $\begin{array}{l}\text { s; } K 49= \\
\text { e; } M=M \\
\text { pound. }\end{array}$ & $\begin{array}{l}\text { L9; K29 }=\mathrm{Ke} \\
\mathrm{s} ; \mathrm{SMC}=\mathrm{S}-\mathrm{gla}\end{array}$ & $\begin{array}{r}29 \text {; } \\
\text { heet }\end{array}$ \\
\hline
\end{tabular}


Table 3. Fatigue and ultimate speed tests results from MEST Program

\begin{tabular}{|c|c|c|c|c|}
\hline & \multicolumn{4}{|c|}{ Flywhee1 design } \\
\hline & Disk & Disk/rim & $\begin{array}{l}\text { Subcircular } \\
\text { rim }\end{array}$ & $\begin{array}{c}\text { Bidirectional } \\
\text { weave }\end{array}$ \\
\hline Material & $\mathrm{SGL}^{\mathrm{a}}$ & $\mathrm{SGL}^{\mathrm{a}} / \mathrm{G}$ & K49 & K49 \\
\hline $\begin{array}{l}\text { Completed } 10,000 \\
\text { Cycle Test }\end{array}$ & Yes & Yes & No ${ }^{b}$ & $-c$ \\
\hline $\begin{array}{l}\text { U1timate Energy Density } \\
(\mathrm{kJ} / \mathrm{kg})\end{array}$ & $175^{\mathrm{d}}$ & $229^{d}$ & 237 & 134 \\
\hline $\begin{array}{l}\text { Total stored energy } \\
(\mathrm{MJ})\end{array}$ & 1.86 & 2.32 & 2.24 & 1.50 \\
\hline $\begin{array}{l}\text { Speed at failure } \\
\quad(\mathrm{rpm})\end{array}$ & 40,638 & 47,058 & 30,012 & 27,575 \\
\hline
\end{tabular}

as-glass laminate.

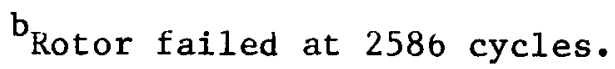

$c_{\text {Rotor was not cycle tested. }}$

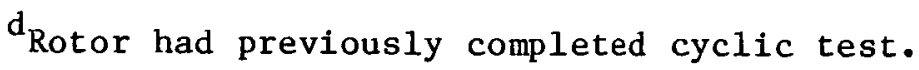


Table 4. Test results for advanced flywheel rotors

\begin{tabular}{|c|c|c|c|c|}
\hline $\begin{array}{l}1985 \\
\text { date }\end{array}$ & $\begin{array}{l}\text { Demo } \\
\text { unit }\end{array}$ & $\begin{array}{l}\text { Velocity } \\
\mathrm{m} / \mathrm{s}\end{array}$ & $\begin{array}{c}\text { Rim } \\
\text { specific } \\
\text { energy } \\
\mathrm{kJ} / \mathrm{kg}(\mathrm{Wh} / \mathrm{kg})\end{array}$ & Result \\
\hline Oct. 17 & $1 \mathrm{~A}$ & 1055 & $495(138)$ & $\begin{array}{l}\text { Web failure, small } \\
\text { crack. No rim damage. }\end{array}$ \\
\hline Nov. 8 & $1 B$ & 1173 & $605(168)$ & $\begin{array}{l}\text { Stopped for inspec- } \\
\text { tion. No damage. }\end{array}$ \\
\hline Nov. 12 & $1 \mathrm{C}$ & 1221 & $663(184)$ & $\begin{array}{l}\text { Stopped for inspec- } \\
\text { tion. No damage. }\end{array}$ \\
\hline Dec. 9 & $1 \mathrm{C}$ & 1405 & $878 \quad(244)$ & $\begin{array}{l}\text { Intentional failure } \\
\text { test. }\end{array}$ \\
\hline
\end{tabular}

Table 5. Flywheel energy storage module characteristics

\begin{tabular}{lccc}
\hline Fiber technology & $\begin{array}{c}\text { Operational storage density } \\
(\mathrm{kJ} / \mathrm{kg})\end{array}$ & $\begin{array}{c}\text { Volume } \\
\left(\mathrm{m}^{3}\right)\end{array}$ & $\begin{array}{c}\text { Volumetric } \\
\text { storage density } \\
\left(\mathrm{MJ} / \mathrm{m}^{3}\right)\end{array}$ \\
\hline Demonstrated & 205 & 1.07 & 177 \\
Within 2 years & 230 & 0.95 & 199 \\
Within 5 years & 325 & 0.67 & 282 \\
\hline
\end{tabular}




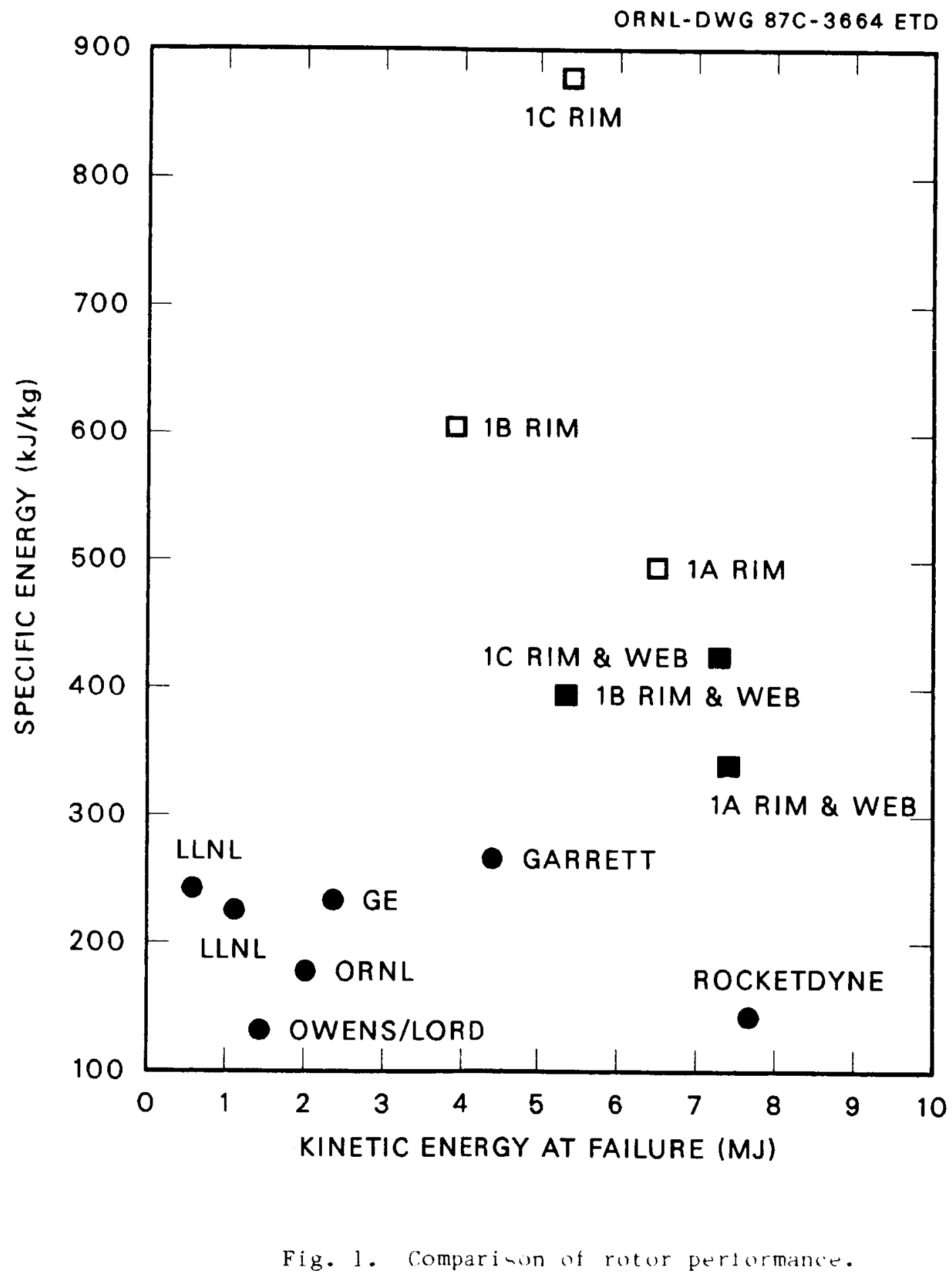




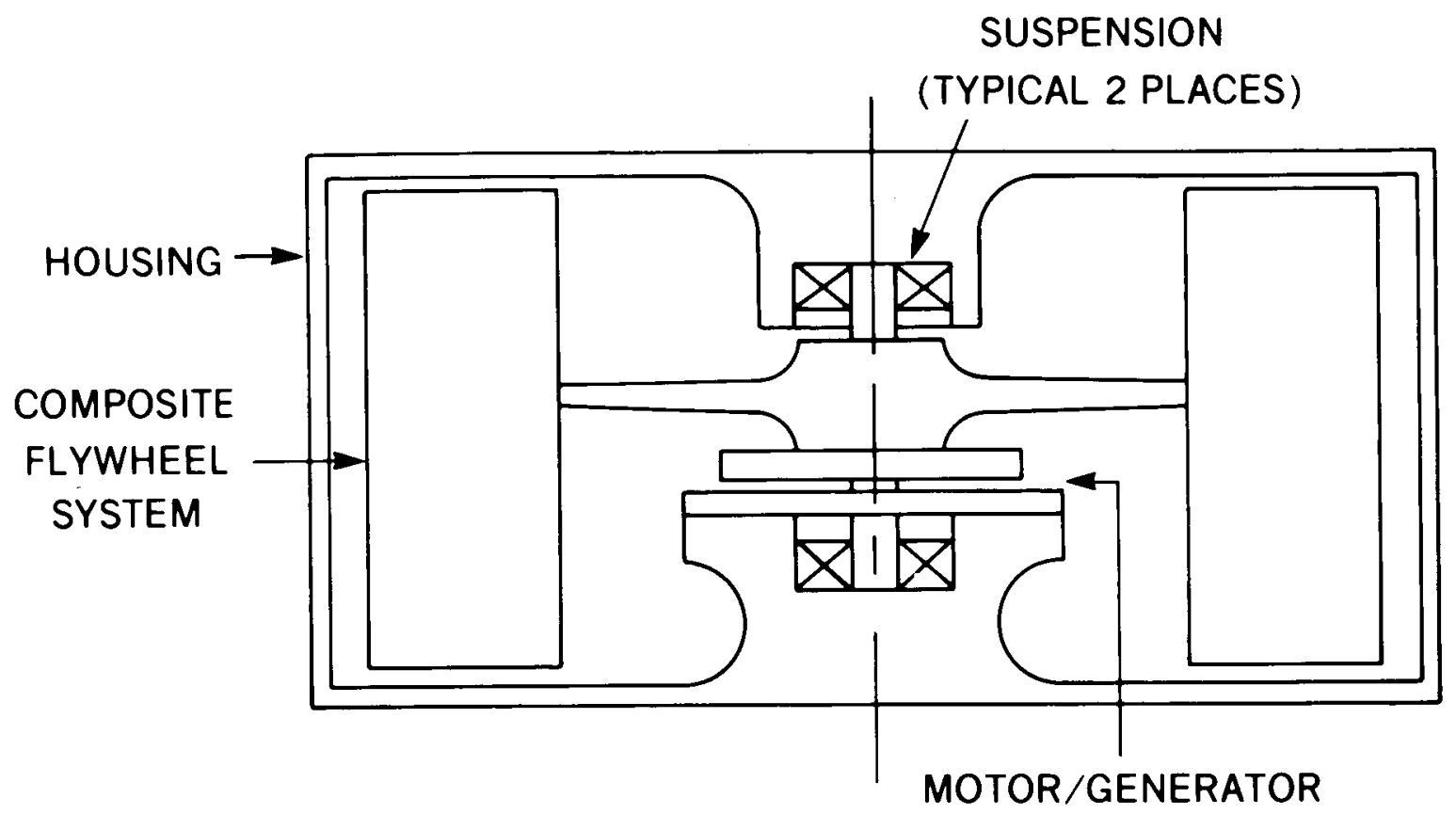

Fig. 2. Schematic of flywheel module for space station application. 